\title{
International law protecting the environment during armed conflict: gaps and opportunities
}

\section{Michael Bothe, Carl Bruch, Jordan Diamond, and David Jensen}

\footnotetext{
Michael Bothe is Professor emeritus of public and international law, J.W. Goethe University, Frankfurt-am-Main; President of the International Humanitarian Fact-Finding Commission; and Chair, German Red Cross Commission on International Humanitarian Law.

Carl Bruch is a Senior Attorney at the Environmental Law Institute, where he co-directs the International Programs. He is also $\mathrm{Co}$-Chair of the Specialist Group on Armed Conflict and the Environment of the IUCN Commission on Environmental Law. Jordan Diamond is a Staff Attorney at the Environmental Law Institute, where she is the Assistant Director of the 0cean Program. David Jensen heads the Policy and Planning Team of UNEP's Post-Conflict and Disaster Management Branch in Geneva.
}

\begin{abstract}
There are three key deficiencies in the existing body of international humanitarian law (IHL) relating to protection of the environment during armed conflict. First, the definition of impermissible environmental damage is both too restrictive and unclear; second, there are legal uncertainties regarding the protection of elements of the environment as civilian objects; and third, the application of the principle of proportionality where harm to the environment constitutes 'collateral damage' is also problematic. These gaps present specific opportunities for clarifying and developing the existing framework. One approach to addressing some of the inadequacies of IHL could be application of international environmental law during armed conflict. The detailed norms, standards, approaches, and mechanisms found in international environmental
\end{abstract}


law might also help to clarify and extend basic principles of IHL to prevent, address, or assess liability for environmental damage incurred during armed conflict.

War and warfare cause not only human suffering and displacement, as well as damage to homes and infrastructure, but also extensive destruction and degradation of the environment. These impacts persist long after the conflict has ended. In this article, the authors explore the structural deficiencies and uncertainties of the existing international legal framework - specifically international humanitarian law (IHL) and international environmental law (IEL) - to address the environmental impacts of armed conflicts.

The direct and indirect protections that IHL offers for the environment during armed conflict are of problematic value. Few IHL provisions explicitly address environmental protection during armed conflict, and those that do are inadequate. Conversely, IEL is an extensive body of law protecting the environment and provides a growing body of standards and mechanisms for addressing environmental harm - and increasingly including issues of liability - during times of peace. Whether and to what extent IEL continues to apply and provide protection during armed conflict, however, is a matter of debate.

The authors highlight a few key gaps and deficiencies in IHL, and then consider opportunities that exist at the intersection of these two bodies of law. The article begins with an analysis of three key weaknesses in the existing body of IHL. First, Additional Protocol I to the 1949 Geneva Conventions defines the threshold of impermissible environmental damage (it must be 'widespread, long-term and severe' $)^{1}$ in a way that is both excessively restrictive and unclear. Second, the provisions of IHL on the protection of civilian objects do not include a sufficient protection of elements of the environment from harm during armed conflict. Third, the proportionality of harm to the environment deemed 'collateral damage' is difficult to determine. For each of these gaps, specific opportunities of redressing the problem are presented.

The article then examines ways in which IEL may address some of the inadequacies of IHL in protecting the environment during armed conflict. Yet questions remain about the general applicability of IEL during hostilities and also the application of particular types of IEL provision. Some treaties expressly state whether they continue during armed conflict (e.g. certain provisions of the World Heritage Convention ${ }^{2}$ ), while others only indirectly address the issue (e.g. the Ramsar Convention ${ }^{3}$ ) or remain silent on it (e.g. the Convention on Biological

1 Protocol Additional to the Geneva Conventions of 12 August 1949, and relating to the Protection of Victims of International Armed Conflicts (Protocol I) of 8 June 1977, Arts. 35(3) and 55(1).

2 Convention for the Protection of the World Cultural and Natural Heritage, 16 November 1972, 1037 UNTS 151.

3 Convention on Wetlands of International Importance especially as Waterfowl Habitat, 2 February 1971, 996 UNTS 245. 
Diversity). Moreover, there are several theories regarding the appropriate method for determining whether IEL continues to apply during armed conflict, and whether the answer to these questions varies for multilateral environmental agreements, principles of IEL, and customary international environment law. While diverse, these approaches highlight opportunities to complement the existing IHL provisions for protecting the environment during armed conflicts and to help answer the question whether and to what extent these IEL norms, standards, approaches, and mechanisms may be applied to prevent, address, or assess liability for environmental damage incurred during armed conflict.

\section{International humanitarian law: gaps and opportunities}

Armed conflict causes both direct and indirect environmental damage, which can endanger people's health, livelihoods, and security. To address these risks, IHL has incorporated fundamental environmental protections into the legal framework governing armed conflict.

A number of scholars have examined in great detail environmental protection under IHL. ${ }^{4}$ Without attempting to catalogue all the relevant IHL provisions, the following analysis highlights a number of gaps and opportunities in the existing IHL framework. This section includes a brief history of IHL lawmaking; threshold questions of Additional Protocol I; elements of the environment as civilian objects; and proportionality of environmental damage as collateral damage.

\section{Armed conflict and environment: a brief history of lawmaking}

In the early 1970s, two developments occurred: the international community began addressing environmental protection generally, and it also made a serious attempt to remedy the deficiencies of legal protection for victims of armed conflict. Both developments were prompted by a scandalization of public opinion triggered by a number of key events. In the international environmental realm, these were environmental disasters such as major oil spills, as well as a broad citizens' movement. As to the law of armed conflict, the developments were the Vietnam War, the protection of human rights in occupied territories (and specifically in Palestine), and the armed conflicts that occurred during decolonization. These two focal points of public opinion came together in a single event: the environmental

4 For a review of IHL governing the environment during armed conflict, see United Nations Environment Programme (UNEP), Protecting the Environment During Armed Conflict: An Inventory and Analysis, Nairobi, 2009; see also Daniel Bodansky, Legal Regulation of the Effects of Military Activity on the Environment, Berichte des Umweltbundesamts/Reports of the German Federal Environment Agency, Nr. 5/2003, Erich Schmidt Verlag, Berlin, 2003; Michael Bothe, 'The protection of the environment in times of armed conflict', in German Yearbook of International Law, Vol. 34, 1991, pp. 54-62; Jay E. Austin and Carl E. Bruch (eds), The Environmental Consequences of War: Legal, Economic, and Scientific Perspectives, Cambridge University Press, Cambridge, 2000. 
and public health effects of defoliation associated with the use of herbicides (particularly Agent Orange) during the Vietnam War.

While lawmaking in the international environmental field left this problem at the margins, the issue was directly addressed by international conferences dealing with armed conflict - to the great dismay of those defending military interests. These conferences included the United Nations Committee of the Conference on Disarmament (CCD) and the Diplomatic Conference on the Reaffirmation and Development of International Humanitarian Law (CDDH, Geneva, 1974-1977).

In 1976, the CCD adopted the Convention on the Prohibition of Military or Any Hostile Use of Environmental Modification Techniques (ENMOD). This treaty regulates the use of environmental modification techniques as a means to cause harm to the enemy. ENMOD specifically prohibits 'environmental modification techniques having widespread, long-lasting or severe effects as the means of destruction'. The travaux of the CCD indicate how to interpret these key terms: 'long-lasting', for instance, signifies 'lasting for a period of months, or approximately a season'. ${ }^{6}$

The more difficult questions were addressed by the $\mathrm{CDDH}$ when it discussed the adoption of two important provisions in what became Additional Protocol I. First, Article 35, paragraph 3, states that ' $\mathrm{i}] \mathrm{t}$ is prohibited to employ methods and means of warfare which are intended, or may be expected, to cause widespread, long-term and severe damage to the natural environment'. Second, Article 55 of Additional Protocol I states that '[c]are shall be taken in warfare to protect the natural environment against widespread, long-term and severe damage'. It further specifies that this protection 'includes a prohibition of the use of methods and means of warfare which are intended or may be expected to cause such damage to the environment and thereby to prejudice the health or survival of the population'.

These provisions were negotiated and adopted with knowledge of the CCD text. ${ }^{7}$ Thus, the differences between the texts are not an oversight but intentional. The three conditions, or the threshold, of the prohibition in Additional Protocol I are cumulative (joined by 'and'), while the conditions in ENMOD are alternatives (joined by 'or'). Furthermore, the meaning of the three adjectives limiting the scope of prohibited damage differs (at least according to the negotiating history of the two provisions) depending on whether they are being interpreted in the context of Additional Protocol I or ENMOD. The competent Conference committee intensively discussed all three in the context of Additional Protocol I.

5 Convention on the Prohibition of Military or Any Other Hostile Use of Environmental Modification Techniques (ENMOD), 10 December 1976, 1108 UNTS 151, Art. 1.

6 Understanding annexed to the text of ENMOD, contained in the report of the UN Committee of the Conference on Disarmament to the General Assembly, Official Records of the General Assembly, 31st Session, Supplement No. 27 (A/31/27).

7 See Waldemar A. Solf, 'Article 55: protection of the natural environment', in Michael Bothe, Karl Josef Partsch, and Waldemar A. Solf, New Rules for Victims of Armed Conflict: Commentaries on the Two 1977 Protocols Additional to the Geneva Conventions of 1949, Nijhoff, The Hague, 1982, p. 347. 
With regard to the time or duration element, the report of the committee states that the duration:

was considered by some to be measured in decades. Reference to twenty or thirty years were made by some representatives as being a minimum ... [I]t is impossible to say with certainty what period of time might be involved. It appeared to be a widely shared assumption that battlefield damage incidental to conventional warfare would not normally be proscribed by this provision. ${ }^{8}$

This definition radically differs from the one accepted in the travaux of ENMOD just quoted. As a consequence, negotiators assumed that, in practice, these provision would 'not impose any significant limitation on combatants waging conventional warfare?. ${ }^{9}$ It might leave room for application to biological and chemical warfare. As to nuclear warfare, however, most NATO countries claim that Additional Protocol I does not apply thereto, ${ }^{10}$ and at least the United States and the United Kingdom contest that these two provisions constitute customary law. ${ }^{11}$ The environmental community has never considered this situation satisfactory.

As a result, a debate arose about further lawmaking. A number of events, primarily the oil spills caused by the 1980-1988 and 1990-1991 Gulf Wars, sustained public debate on the issue. There were, for example, far-reaching demands for new international law - a 'Fifth Geneva Convention'. Those efforts, however, met considerable resistance from important military powers. The only tangible result of the efforts to adopt new documents was a set of Guidelines on environmental protection during armed conflict, elaborated by the International Committee of the Red Cross (ICRC) and published in 1994. ${ }^{12}$ These Guidelines, however, did not constitute any significant progress for better protection of the environment during armed conflict, and even this modest document received a somewhat hostile reception at the UN. The UN General Assembly politely buried it in $1994 .^{13}$

The next step in lawmaking was the 1998 Rome Statute, ${ }^{14}$ establishing the International Criminal Court. In its definition of war crimes, the Rome Statute

8 Conference document CDDH/215/Rev. 1, para. 27.

9 W. A. Solf, above note 7, p. 348.

10 United States, declaration made on signature: 'It is the understanding of the United States of America that the rules established by this protocol were not intended to have any effect on and do not regulate or prohibit the use of nuclear weapons'. United Kingdom, declaration made on ratification: 'It continues to be the understanding of the United Kingdom that the rules introduced by the Protocol apply exclusively to conventional weapons without prejudice to any other rules of international law applicable to other types of weapons. In particular, the rules so introduced do not have any effect on and do not regulate or prohibit the use of nuclear weapons'.

11 For references, see Jean-Marie Henckaerts and Louise Doswald-Beck, Customary International Humanitarian Law, International Committee of the Red Cross and Cambridge University Press, Cambridge, 2005, Vol. I, pp. 153ff.

12 International Committee of the Red Cross (ICRC), Guidelines for Military Manuals and Instructions on the Protection of the Environment in Times of Armed Conflict, Geneva, 1994.

13 General Assembly resolution 49/50 of 9 December 1994; for a comment, see Michael Bothe, 'Military activities and the protection of the environment', in Environmental Policy and Law, Vol. 37, No. 2-3, 2007, p. 234.

14 Rome Statute of the International Criminal Court (ICC) of 17 July 1998, A/CONF.138/9. 
contains a provision protecting the environment in times of international armed conflict:

Intentionally launching an attack in the knowledge that such attack will cause incidental loss of life or injury to civilians or damage to civilian objects or widespread, long-term and severe damage to the natural environment which would be clearly excessive in relation to the concrete and direct overall military advantage anticipated. ${ }^{15}$

This provision is related, but not identical to, three provisions of Additional Protocol I. These include Article 51(5)(b), prohibiting attacks that cause 'excessive' collateral damage to civilians or civilian objects, and the two provisions concerning the environment quoted above (Articles 35(3) and 55).

To assess the significance of the Rome Statute provision, one has to bear in mind that criminal law contains secondary norms. They constitute means to enforce a primary obligation. As such, they need not be identical to those primary obligations. While a provision of international criminal law presupposes a primary norm prohibiting the behaviour that constitutes a crime, many primary obligations do not trigger criminal sanctions. Thus, a more narrow criminal provision on environmental damage during armed conflict (holding individuals personally and criminally liable) does not alter the underlying primary obligation of states, under existing international law, to prevent a broader range of environmental damage.

The lack of clarity surrounding the bounds of treaty obligations to avoid damaging the environment during armed conflict raises the question of environmental protection under customary humanitarian law and the treatment of the question by the Customary International Humanitarian Law Study published by the ICRC in 2005. ${ }^{16}$ The Study declares a simplified version of the provisions of Additional Protocol I and of ENMOD to constitute customary law, stating that the 'use of methods and means of warfare that are intended, or may be expected, to cause widespread, long-term and severe damage to the natural environment is prohibited. Destruction of the natural environment may not be used as a weapon'. ${ }^{17}$

A real step forward was accomplished via another rule articulated in the Study. Rule 44 states that

$[\mathrm{m}]$ ethods and means of warfare must be employed with due regard to the protection and preservation of the natural environment. In the conduct of military operations, all feasible precautions must be taken to avoid, and in any event to minimise, incidental damage to the environment. ${ }^{18}$

16 J.-M. Henckaerts and L. Doswald-Beck, above note 11.

17 Ibid., Rule 45.

18 Ibid., Rule 44. 
In addition, a ' $[1]$ ack of scientific certainty as to the effects on the environment of certain military operations does not absolve a party to the conflict from taking such precautions'. ${ }^{19}$

The rule uses a variation of the general IHL rule that 'precautionary measures' must be taken to avoid damage to civilians and civilian objectives ${ }^{20}$ The last sentence of Rule 44, however, constitutes an application of the precautionary principle, well established in IEL, to the duty to take precaution in armed conflict, which in the latter context amounts to a revolution. The Study quotes limited state practice to support this rule. The majority of the support cited is the reading of two decisions of the International Court of Justice (ICJ), namely the 1995 Nuclear Tests case order and the 1996 Nuclear Weapons advisory opinion. ${ }^{21}$ The Study in effect argues that recognition of the precautionary principle as customary international environmental law must be reflected in the law of armed conflict.

The 'due regard' principle formulated in Rule 44 seems to be well accepted. This is elucidated by two private, yet semi-official, restatements of relevant rules. The San Remo Manual on International Law Applicable to Armed Conflict at Sea (1994) states that ' $[\mathrm{m}]$ ethods and means of warfare should be employed with due regard for the natural environment .... 22 The HPCR Manual on International Law Applicable to Air and Missile Warfare (2009) formulates rules along the same lines, stating that the 'destruction of the natural environment carried out wantonly is prohibited' ${ }^{23}$ It also urges that ' $[w]$ hen planning and conducting air and missile operations, due regard ought to be given to the natural environment'. ${ }^{24}$

It is submitted that the prohibition of 'wanton' destruction of natural environment elements and the due regard principle are both more favourable for the environment and more flexible than the provisions of Additional Protocol I.

\section{Additional Protocol I and the threshold question}

As noted above, the crucial problem raised by Additional Protocol I is the meaning of the three conditions attached to the prohibition on 'long-term, widespread and severe' damage to the environment. ${ }^{25}$ The narrow scope of the prohibition is due both to the cumulative character of the three conditions and to their interpretation, which effectively sets the threshold very high, but also with some ambiguity.

19 Ibid.

20 Additional Protocol I, Art. 57.

21 ICJ, Request for an Examination of the Situation in Accordance with Paragraph 63 of the Court's Judgment of 20 December 1974 in the Nuclear Tests (New Zealand $v$. France) Case, Order of 22 September 1995, ICJ Reports, 1995; ICJ, Legality of the Threat or Use of Nuclear Weapons, Advisory Opinion of 8 July 1996, ICJ Reports, 1996.

22 San Remo Manual on International Law Applicable to Armed Conflict at Sea, reproduced in Dietrich Schindler and Jiři Toman (eds), The Laws of Armed Conflict, 4th edition, Leiden and Boston, 2004, p. 1153 , Rule 44.

23 Harvard University, Program on Humanitarian Policy and Conflict Research (HPCR), Manual on International Law Applicable to Air and Missile Warfare, Bern, 2009, Rule 88.

24 Ibid., Rule 89.

25 Additional Protocol I, Arts. 35(3) and 55(1). 
At least if interpreted in the light of the negotiating history, ${ }^{26}$ it seems next to impossible that the threshold could be reached by conventional warfare. Regarding chemical warfare, the only practical case thus far (the use of herbicides in Vietnam) raises some doubts. If the yardstick for 'long-lasting' is several decades, the threshold might not have been reached. Nature has recovered in many but not all places in Vietnam; however, damage to human health remains, and may last for generations.

The above interpretation is not necessarily generally accepted nowadays, but it is safe to state that the parties to the treaty intended to establish a very high threshold. Natural resources and the environment are essential to post-conflict peacebuilding, ${ }^{27}$ and significant environmental damage can undermine efforts to provide for livelihoods, promote economic recovery, and allow society to return to a 'normal' peacetime way of life. A framework that is too permissive of environmental damage during armed conflict can thus undermine long-term peace.

One can ask whether this high threshold is still valid, or whether it has fallen into desuetude ${ }^{28}$ in light of the continually increasing recognition of environmental concerns in international relations. This is arguable, but not certain.

This brings us to gap number one: for two reasons, the legal situation is highly unsatisfactory from an environmental point of view. First, the conditions attached to the prohibition of Articles 35 and 55 of Additional Protocol I are excessively restrictive, making the prohibition much too narrow from an environmental point of view. Second, the exact scope of this prohibition remains uncertain, and thus difficult to implement or enforce.

This gap presents an opportunity, however: an alternative form of legal protection for the environment in times of armed conflict appears in a number of documents purporting to reflect customary law - namely, the 'due regard' principle and the prohibition of 'wanton' destruction. Whether and how this can be clarified remains an open question.

\section{Elements of the environment as civilian objects}

Elements of the environment are most often civilian objects. As such, they are protected against attacks. To that extent, the restrictive conditions of Articles 35 and 55 of Additional Protocol I do not apply. This protection is, however, shaky, as environmental elements can easily become military objectives. Once armed forces are located in a protected area, the area may contribute effectively to military action and its neutralization may offer a definite military advantage. Thus, it becomes a military objective. In the case of herbicide use in Vietnam, the trees provided cover

26 See W. A. Solf, above note 7, p. 348; Conference document CDDH/215/Rev. 1, para. 27.

27 Carl E. Bruch et al., 'Post-conflict peace building and natural resources', in Ole Kristian Fauchald, David Hunter, and Wang Xi (eds), Yearbook of International Environmental Law, Vol. 19, 2008, Oxford University Press, Oxford, 2009.

28 Desuetude is the legal rule that provides that a legal provision loses its binding force as the result of nonuse for a sufficiently long time. 
for the enemy. Their defoliation constituted a definite military advantage, and the trees - more precisely their leaves - became a military objective.

This brings us to the second gap in IHL: elements of the environment are all too likely to become military objectives, invalidating their protections as civilian objects. In theory, Articles 35 and 55 of Additional Protocol I could restrain environmental destruction, but this brings us back to gap number one.

Gap number two provides opportunity number two: the transformation of environmental elements into military objectives must be prevented. How can this be achieved? Articles 59 and 60 of Additional Protocol I (non-defended localities and demilitarized zones) may serve as a model. Because there is no military presence in these areas, they are not or are no longer military objectives, and therefore are immune from attack. In the same way, environmentally sensitive areas may be rendered immune against attacks by excluding any military presence. In the absence of a treaty to that effect, this cannot be achieved by a unilateral declaration. Whether a new treaty is possible is highly doubtful, at least in the near future. Nevertheless, the parties to a conflict can achieve the same result by mutual agreement, such as through mediation led by the ICRC, the UN, or a relevant environmental organization. ${ }^{29}$ An international organization could call upon the parties to conclude such agreements. Finally, the UN Security Council, in the exercise of its powers under Chapter VII of the UN Charter, could designate such protected areas and oblige the parties to conclude such agreements.

\section{Environmental damage as collateral damage: the question of proportionality}

The environment may be damaged indirectly by attacks against military objectives. This is the case with oil spills (if the direct target is a military objective) or pollution caused by attacks against industrial installations. In this case, the elements of the environment that are affected constitute civilian objects. Damage to these environmental objects would then be 'collateral damage', which is permissible only to the extent that it is not excessive in relation to the concrete and direct military advantage anticipated as a result of the attack. This raises a number of difficult questions.

As a rule, there will be uncertainties regarding the environmental impacts of the collateral damage. Where damage occurs outside military objectives (for example, an oil spill caused by the attack against a power station situated near the coast), it is first necessary to assess the extent of the environmental damage, which can be quite difficult. To assess the damage caused by the attack, it is necessary to

29 Informal working groups of the International Union for Conservation of Nature (IUCN) have advanced this solution for a number of years. It is now contained in an official statement of the ICRC, Strengthening Legal Protection for Victims of Armed Conflicts: The ICRC Study on the Current State of International Humanitarian Law, Address by Dr Jakob Kellenberger, President of the ICRC, 21 September 2010, in this issue, also available at: http:/www.icrc.org/web/eng/siteeng0.nsf/htmlall/ihl development-statement-210910 (last visited 18 October 2010). 
determine not only the extent of pollution and the harm caused after the attack but also the amount of pre-existing pollution and its effects. There is also the uncertainty involved in predicting long-term damage. ${ }^{30}$

Assuming it is possible to clarify the relevant facts regarding the damage, what is the legal yardstick of proportionality? This is already difficult in the case of simple physical damage. It becomes all the more difficult in the case of environmental damage, in particular long-term damage. Is the precautionary principle relevant in determining the relative weight of environmental values in the so-called proportionality equation? In other words, can an environmental damage be 'excessive' within the meaning of Article 51 of Additional Protocol I even if the full extent and nature of the damage are not certain?

If an element of the environment is lawfully attacked because it constitutes a military objective, there might be long-term environmental damage beyond the actual destruction. Are Articles 35 and 55 of Additional Protocol I lex specialis for determining the lawfulness of that long-term damage, and thus not subject to the principle of proportionality under IHL? Alternatively, is this long-term damage a form of 'collateral' damage that would then be subject to the yardstick of proportionality?

This brings us to the third gap: there is a lack of clarity about the practical issues of proportionality where environmental damage is collateral damage, caused by attacks against military objectives.

These issues of proportionality also provide the third opportunity, which is to clarify proportionality. A new treaty, even assuming it were politically possible, would be unlikely to resolve the issue, at least for the substantive problems involved. It seems problematic - if not impossible - to provide a general solution that applies to all possible situations of environmental collateral damage. However, general rules for assessing environmental damage could be helpful. They could be established by resolutions of relevant international organizations. As to the substantive issues, the best solution would probably be for expert groups to analyse typical scenarios and develop a set of criteria for determining proportionality.

\section{Conclusions on international humanitarian law}

IHL provisions that are relevant for environmental protection during armed conflict constitute a body of treaty and customary law with significant gaps and deficiencies.

First, the primary provisions that directly protect the environment during armed conflict - Articles 35 and 55 of Additional Protocol I - do not adequately achieve this aim because the 'widespread, long-term and severe' damage threshold is imprecise and difficult to meet, leaving much of the serious environmental harm

30 See, e.g., Asit Biswas, 'Scientific assessment of the long-term environmental consequences of war', in J. E. Austin and C. E. Bruch, above note 4. 
arguably outside the scope of current protections. Thus, these terms require clear and more appropriate definitions.

Second, because few IHL norms explicitly address environmental protection, indirect means may provide more effective protection by regulating the means and methods of warfare or by protecting civilian persons and objects. However, the gap here is that elements of the environment are likely to become military objectives, which brings us back to gap number one. This problem may be solved by using Articles 59 and 60 of Additional Protocol I (non-defended localities and demilitarized zones) as a model for rendering environmentally sensitive areas immune.

Third, there is a lack of clarity surrounding collateral damage to civilian objects as a result of attacks against military objectives. The gap here is a lack of clarity about the practical proportionality issues where environmental damage is collateral damage, caused by attacks against military objectives.

There are other deficiencies in the existing IHL framework. ${ }^{31}$ These include, for example, uncertainties in IHL governing protection of the environment during non-international armed conflict. ${ }^{32}$ This is problematic, as the vast majority of current armed conflicts are non-international.

\section{Application of international environmental law during armed conflict ${ }^{33}$}

In the light of the significant gaps and deficiencies in the IHL framework regarding the protection of the environment during armed conflict, it must be asked whether some of these gaps could be addressed through the application of international environmental law (IEL). IEL provides a well-established body of norms, standards, approaches, and mechanisms preventing and redressing-including through responsibility and, increasingly, liability-damage to the environment during times of peace. With the development, maturation, and application of a substantial body of law governing environmental use and protection, the question is whether and to what extent these provisions of IEL continue to apply during armed conflict and whether they provide a meaningful protection against the specific risks of warfare. IEL rules protecting certain natural resources are one example to be considered. Their ability to restrain waste and destruction by warfare has to be assessed. Rules that prohibit the causation of specific types of environmental damage should also be taken into account. To use an example referred to above, if a power station is destroyed during a war or other military operation (as happened with the power plant at Jiyeh, Lebanon, in 2006), should the subsequent oil spill trigger an institutional mechanism for response and clean-up or a

31 See generally UNEP, above note 4 .

32 A differentiated answer is given by J.-M. Henckaerts and L. Doswald-Beck, above note 11, Vol. I, pp. $148 \mathrm{ff}$. and $156 \mathrm{ff}$.

33 The following section draws from the authors' analyses in UNEP, above note 4. 
liability regime $?^{34}$ Would the World Heritage Convention, which protects sites of cultural and natural heritage, ${ }^{35}$ prohibit targeting or causing extensive harm to a World Heritage site during military activities?

Questions regarding the application of IEL during armed conflict are complicated for two reasons. First, environmental law is still dynamic, and it keeps developing. Second, this is part of the general phenomenon of fragmentation of international law, which entails the question of how, in the case of overlapping fields of application, different regimes or bodies of international law relate to each other. Scholarship and commentary provide several perspectives on whether IEL applies during armed conflict. Starting in the 1990s, there has been a noticeable shift in the historic belief that laws applicable during war and peace were mutually exclusive. Contemporary perspectives increasingly bridge the two bodies of law, applying peacetime international law during armed conflict to varying degrees. Where both bodies of law apply concurrently, however, the question of their relationship (lex specialis) also has to be answered.

This development is clearly documented in the work of the International Law Commission (ILC). In 2004, the General Assembly approved the ILC's proposal to include work on the 'effects of armed conflict on treaties' in its long-term programme. In 2008, that work resulted in a set of draft articles that attempt to regulate the applicability of treaties during armed conflicts. ${ }^{36}$ The draft articles state that the onset of armed conflict 'does not necessarily terminate or suspend the operation of treaties' between belligerents or belligerents and neutral parties. ${ }^{37}$ Rather, this is determined by a complex body of different considerations: express provisions and subject matter of the treaty, treaty interpretation according to Articles 31 and 32 of the Vienna Convention on the Law of Treaties (VCLT) of 23 May 1969, the nature and extent of the armed conflict, and the effect of the armed conflict on the treaty. ${ }^{38}$ What this means in practice has to be ascertained on a case-by-case basis.

34 The International Convention on the Establishment of an International Fund for Compensation for Oil Pollution Damage, 18 December 1971, 1110 UNTS 57, and the International Convention on Civil Liability for Oil Pollution Damage, 29 November 1969, 973 UNTS 3, only apply to oil pollution from ships. In Jiyeh, on-the-ground assistance was provided pursuant to the Protocol Concerning Cooperation in Combating Pollution of the Mediterranean Sea by Oil and other Harmful Substances in Cases of Emergency (Emergency Protocol), Barcelona, 16 February 1976.

35 A question that also deserves attention in this context is whether the Convention for the Protection of Cultural Property in the Event of Armed Conflict, 14 May 1954, 249 UNTS 215, provides a more appropriate protection in cases where heritage sites are at the same time cultural property.

36 International Law Commission (ILC), Report of the International Law Commission, 59th Session, 7 May-5 June and 9 July-10 August 2007, paras. 266-324, UNGA Supp. A/62/10; ILC, Effects of Armed Conflicts on Treaties, UN Doc. A/CN.4/L.727/Rev.1, 6 June 2008; ILC, Effects of Armed Conflicts on Treaties, Addendum, UN Doc. A/CN.4/L.727/Rev.1/Add.1, 11 July 2008. The draft articles were provisionally adopted and circulated to states for comment and observation, to be submitted by January 2010: ILC, Report of the International Law Commission, 60th Session, 5 May-6 June and 7 July-8 August 2008, para. 14, UNGA Supp. A/63/10.

37 ILC, Effects of Armed Conflicts on Treaties, 6 June 2008, above note 36, Art. 3.

38 Ibid., Art. 4. 
This part of the article provides an overview and analysis of law and commentary addressing IEL applicability during armed conflict. It is organized in three main sections: (a) multilateral environmental agreements that might be applied; (b) customary international environmental law and soft-law instruments that might be applied; and (c) commentary on the applicability of these two bodies of IEL during armed conflict.

\section{Multilateral environmental agreements}

With regard to the question of whether and to what extent multilateral environmental agreements (MEAs) continue to protect the environment in times of armed conflict, a basic distinction has to be made, which is also a basic problem. As a rule, the law applicable in times of peace applies between belligerents and neutral states (more generally, states not parties to an armed conflict). This means that, at least as a matter of principle, an MEA must continue to apply during an armed conflict at least in the relation between the parties to the conflict and the states that are not parties. From this perspective, the continued application of an MEA during an armed conflict only constitutes a problem in the relationship between belligerents. In addition, and in line with this logic, the existence of a non-international armed conflict arising on the territory of a party to an MEA does not affect the application of the treaty. The situation is not, however, as simple as that. The fundamental question of whether a state involved in an armed conflict, whether an international armed conflict or a non-international one, can be expected to fulfil its international obligations in the same way as if the conflict did not exist has to be asked and answered. The clausula rebus sic stantibus ${ }^{39}$ and necessity as a circumstance precluding wrongfulness ${ }^{40}$ may modify the relationship between parties and nonparties to an armed conflict in comparison to their relationship in time of peace. While the basic distinction between the relationship between belligerents and the one between belligerents and non-belligerents has to be maintained, a closer look at the scope of that distinction is necessary, taking into account the basic content of relevant MEAs.

How instruments of IEL address their applicability during times of armed conflict varies substantially. Some MEAs directly or indirectly provide for their continued application during hostilities, while others specifically state that they are automatically suspended, terminated, or inapplicable once armed conflict has begun; others remain silent on the issue. Unfortunately, most MEAs fall into the third category, so there is substantial uncertainty. ${ }^{41}$

39 VCLT, Art. 62.

40 ILC, 'Responsibility of states for internationally wrongful acts', in Yearbook of the International Law Commission, Vol. II, Part Two, 2001, pp. 32ff., Art. 25.

41 Relying on lex specialis is not helpful. On the one hand, it may be argued that IHL is lex specialis as it is developed specifically for the context of armed conflict. On the other hand, it can be argued at least as forcefully that IEL is lex specialis as it has much more developed provisions relating to the environment, while IHL only touches on the issue generally. 
An MEA may indirectly provide that it continues to apply during armed conflict. Under the World Heritage Convention, the World Heritage Committee establishes and updates a World Heritage List of cultural heritage and natural heritage properties with 'outstanding universal value'.2 Inclusion on the list requires the concerned state's consent. In addition, the Committee keeps a 'list of World Heritage in Danger' that includes sites that require 'major operations' to conserve, for which assistance has been requested, and that are 'threatened by serious and specific dangers'. Serious and specific dangers may include 'the outbreak or the threat of an armed conflict'. ${ }^{43}$

Another example is found in the Ramsar Convention, which establishes a List of Wetlands of International Importance. ${ }^{44}$ The Convention does not expressly state whether it applies to belligerents; however, intent may be inferred from the Convention's language that a party to the agreement has the right, 'because of its urgent national interests, to delete or restrict the boundaries of wetlands already included by it on the List'. ${ }^{45}$ It is possible, although unclear, that situations of 'urgent national interests' may include armed conflict. ${ }^{46}$ It is notable that urgent national interests do not allow a party to restrict the protective measures of a listed wetland, only to amend its boundaries. The question then arises whether a military use of the area constitutes a violation of the duties of protection established by the Convention.

Similarly, the UN Convention on the Law of the Sea (UNCLOS) ${ }^{47}$ requires states party 'to protect and preserve the marine environment', as well as to take measures to prevent, reduce, and control marine pollution. ${ }^{48}$ Article 236 of UNCLOS, however, establishes a variance for 'any warship, naval auxiliary, other vessels or aircraft owned or operated by a State and used, for the time being, only on government non-commercial service'. Parties are then instructed to 'ensure, by the adoption of appropriate measures not impairing operations or operational capabilities ... that such vessels or aircraft act in a manner consistent, so far as is reasonable and practicable, with this Convention'. ${ }^{49}$ Although the standards applied to military as opposed to non-military vessels and aircraft vary, UNCLOS

42 World Heritage Convention, Art. 11(2).

43 Ibid., Art. 11(4).

44 Ramsar Convention, Art. 2.

45 Ibid., Art. 3. Article 4 of the Ramsar Convention then requires that, when urgent national interests cause a party to make such a deletion or restriction, they should attempt to compensate for that loss of wetlands.

46 See, e.g., Alice Louise Bunker, 'Protection of the environment during armed conflict: one gulf, two wars', in Review of European Community \& International Environmental Law, Vol. 13, No. 2, 2004, p. 211 . We have seen that, although environmental treaties can be applied to situations of armed conflict, their provisions are often too flexible and ambiguous to provide any real guidance to commanders on the battlefield or to be enforced after the event. The only area of environmental law where this is perhaps not true is the protection of areas of special significance such as World Heritage sites or Ramsar wetlands. Here it is clear that a defined area should be avoided and peacetime protections can be more easily linked to wartime activity, as suggested by the IUCN Protected Areas Draft Convention.

47 United Nations Convention on the Law of the Sea (UNCLOS), 10 December 1982, 1833 UNTS 3.

48 Ibid., Arts. 192 and 194; see also Arts. 207-208 and 212.

49 Ibid., Art. 236. 
may continue to apply during armed conflict. ${ }^{50}$ More specific requirements are formulated in the San Remo Manual on International Law Applicable to Armed Conflicts at Sea. ${ }^{51}$ Article 44 of the Manual states that '[d] amage to or destruction of the natural environment not justified by military necessity and carried out wantonly is prohibited'. It also provides that, when hostile actions are undertaken within the exclusive economic zone of a neutral state, belligerents shall 'have due regard for the rights and duties of the coastal State, inter alia, for ... the protection and preservation of the marine environment' ${ }^{52}$

In contrast, some MEAs explicitly suspend, derogate, or terminate the agreement between belligerents during armed conflict. For example, the Convention on Third Party Liability in the Field of Nuclear Energy (1960) exempts operators for damage directly resulting from armed conflict or similar activities, ${ }^{53}$ although Austria and Germany objected to this provision and explicitly declared their right to hold operators liable for such damage. ${ }^{54}$ This is equivalent to the established principle of insurance law that insurance against losses does not cover war damages. Seen in this light, the rule would apply not only to the relationship between belligerents but also to that between belligerents and non-belligerents.

Many MEAs contain no reference to their applicability during armed conflict. Such MEAs include the Convention on Biological Diversity (1992), the UN Convention to Combat Desertification (1994), and the Convention on the Conservation of Migratory Species of Wild Animals (1979).$^{55}$ The effect of their silence, and whether it varies by type of convention, is uncertain. For example, commentary has posited that the Convention on Biological Diversity applies to belligerent parties, as it is analogous to human rights treaties that do not automatically terminate upon hostilities. ${ }^{56}$ This uncertainty raises questions about how parties should proceed, such as whether belligerents should agree on sites to be placed off limits, ${ }^{57}$ or if military entities should be instructed on the principles of the MEAs and charged to abide by them to the extent possible.

50 See, e.g., Michael N. Schmitt, 'Green war: an assessment of the environmental law of international armed conflict', in Yale Journal of International Law, Vol. 22, No. 1, 1997, pp. 47-49, discussing the potential protections that UNCLOS may afford during armed conflict. Silja Vöneky, 'Peacetime environmental law as a basis of state responsibility for environmental damage caused by war', in J. E. Austin and C. E. Bruch, above note 4, p. 207, argues that, because UNCLOS creates an 'objective regime' and intends 'to serve the interests of the state community as a whole', it continues to apply during armed conflict.

51 San Remo Manual, above note 22.

52 Ibid., Art. 34. If mines are laid within a neutral state's exclusive economic zone, the belligerent must notify the neutral state and give '[d]ue regard ... to the protection and preservation of the marine environment' (ibid., Art. 35).

53 Convention on Third Party Liability in the Field of Nuclear Energy, Art. 9, 29 July 1960, amended 28 January 1964, 956 UNTS 264.

54 Ibid., Annex I, para. 4.

55 Convention on Biological Diversity, 5 June 1992, 1760 UNTS 79; United Nations Convention to Combat Desertification, 17 June 1994, 1954 UNTS 3; Convention on the Conservation of Migratory Species of Wild Animals, 23 June 1979, 1651 UNTS 333.

56 See S. Vöneky, above note 50.

57 See above, 'Elements of the environment as civilian objects'. 


\section{Customary international environmental law and soft-law instruments}

Certain soft-law instruments explicitly refer to armed conflict. Other IEL principles and soft-law instruments may apply, although they do not address armed conflict directly. So-called soft-law instruments are not legally binding unless they rise to the level of customary IEL. An example is furnished by arguments discussing whether the precautionary principle and the right to a healthy environment constitute - or are emerging - customary IEL. ${ }^{58}$ Even if a soft-law instrument is deemed to not constitute customary IEL, it may still inform the interpretation and application of international law.

The Declaration of the United Nations Conference on the Human Environment (Stockholm Declaration) $)^{59}$ of 1972 articulated an overarching principle that may bear on IEL applicability during armed conflict. Principle 21 provides that 'States have ... the responsibility to ensure that activities within their jurisdiction or control do not cause damage to the environment of other States or of areas beyond the limits of national jurisdiction' ${ }^{60}$

Two decades later, the Declaration on Environment and Development (Rio Declaration) of 1992 stated in Principle 24 that: 'Warfare is inherently destructive of sustainable development. States shall therefore respect international law providing protection for the environment in times of armed conflict and cooperate in its further development, as necessary' ${ }^{61}$ While the intent to protect the environment is clear, the provision's precise meaning is less so; it may mean that IEL applies during conflict, or it may simply reiterate required state adherence to relevant IHL provisions. ${ }^{62}$

The Rio Conference adopted similar language in the Programme of Action for Sustainable Development (Agenda 21) in Article 39(6), detailing the means of implementation. It states that ' $[\mathrm{m}]$ easures in accordance with international law should be considered to address, in times of armed conflict, large-scale destruction of the environment that cannot be justified under international law'. The Article specifies that the UN General Assembly and Sixth Committee should handle such efforts, with ICRC consideration. ${ }^{63}$

More broadly, Principle 5 of the World Charter for Nature mandates that ' $[\mathbf{n}]$ ature shall be secured against degradation caused by warfare or other

58 A potential complication when analysing what may constitute customary IEL is that there have been few state-by-state assessments to ascertain state practice and opinio juris; most commentaries rely on international declarations and on isolated samples of practice.

59 Declaration of the United Nations Conference on the Human Environment (Stockholm Declaration), 16 June 1972, UN Doc. A/CONF.48/14/Rev. 1 (1973).

60 Ibid., Principle 21. This is the Trail Smelter principle, discussed below.

61 Rio Declaration on Environment and Development, 13 June 1992, UN Doc. A/CONF.151/26, Vol. I, Principle 24.

62 See, e.g., M. N. Schmitt, above note 50, pp. 43-44.

63 Agenda 21: Programme of Action for Sustainable Development, UN GAOR, 46th Session, Agenda Item 21, UN Doc. A/Conf.151/26, 14 June 1992, Art. 39(6). 
hostile activities'. ${ }^{64}$ This principle appears intended to prohibit environmental harm during armed conflict. But it is probably rather a political postulate than the expression of a legal rule. In the light of the controversies surrounding the customary law character of rules protecting the environment in times of armed conflict, such a sweeping rule could not reasonably meet the test of general practice and opinio iuris.

UN General Assembly resolution 47/37, adopted in 1993, urges states to take measures for complying with international law protecting the environment during armed conflict. ${ }^{65}$ Although it also encourages incorporating such international law into military manuals, the precise import of these provisions remains unclear. Its reference to provisions 'applicable to the protection of the environment' may refer to relevant provisions within IHL, or to IEL. The resolution led to the ICRC's development of Guidelines for incorporating environmental protection into military manuals, discussed earlier ${ }^{66}$

While some principles expressly address armed conflict, others - such as the Trail Smelter principle - are silent. Nonetheless, they may be applied to armed conflict. The Trail Smelter principle arose from an arbitral decision resolving a dispute between the United States and Canada regarding transboundary air pollution in which a Canadian smelter harmed US crops and forests downwind of it. ${ }^{67}$ The Trail Smelter arbitral panel held that Canada had a responsibility to prevent harmful transboundary air emissions from the smelter, and was liable for the damages that such emissions incurred. The decision was based on a fundamental responsibility to use one's territory so as not to cause harm to that of another. It must nowadays be considered as a rule of customary international law.

The Trail Smelter principle may afford protection to non-belligerent, neutral territories by establishing state responsibility for environmental damage caused outside the state where the acts or events entailing such damage occur. Certain comments suggest that such allocation might not apply if belligerent interests outweigh the victim state's harm. ${ }^{68}$ Where damage is caused in neutral territory, this thesis is in contradiction with the general principle of the law of neutrality that the neutral territory is inviolable and that the neutral state, as a matter of principle, may not be affected by the armed conflict. There is no basis in state practice for the suggested exception to this customary rule of international

64 UN General Assembly resolution 37/7, 28 October 1982, World Charter for Nature, UN Doc. A/RES/37/7, Principle 5.

65 UN General Assembly resolution 47/37, 9 February 1993, Protection of the Environment in Times of Armed Conflict, UN Doc. A/RES/47/37.

66 See ICRC, above note 12 , and accompanying text. The first military manual specifically instructing environmental protection during hostilities is thought to be the US Department of the Navy's Commander's Handbook on the Law of Naval Operations. See US Navy, US Marine Corps, and US Coast Guard, The Commander's Handbook of the Law of Naval Operations, NWP 1-14M, October 1995; see also Arthur H. Westing, 'In furtherance of environmental guidelines for armed forces during peace and war', in J. E. Austin and C. E. Bruch, above note 4, p. 177.

67 Trail Smelter Case (United States v. Canada), 16 April 1938 and 11 March 1941, Reports of International Arbitral Awards (R.I.A.A.), Vol. III, p. 1905.

68 M. N. Schmitt, above note 50, pp. 46-47. 
law. The frequent reiteration of the Trail Smelter principle indeed indicates the rapid emergence of a state's right to environmental protection as customary IEL that also applies during armed conflict. ${ }^{69}$

This conclusion results, in particular, from the jurisprudence of the International Court of Justice. In the Corfu Channel case, the ICJ practically extended the Trail Smelter principle to the actions of parties during conflict, although the case did not specifically address transboundary pollution. ${ }^{70}$ In this case, the ICJ held Albania responsible for damage from mines laid in Albanian waters to British ships travelling through these waters, observing that international law obliges the state 'not to allow knowingly its territory to be used for acts contrary to the rights of other states'. ${ }^{71}$

The ICJ also recognized the Trail Smelter principle in the 1996 Advisory Opinion on the Legality of the Threat or Use of Nuclear Weapons. ICJ advisory opinions, although not legally binding, provide persuasive evidence of customary international law and the application and implementation of international law. In this advisory opinion, the Court notes that a state's general obligation 'to ensure that activities within their jurisdiction and control respect the environment of other States or of areas beyond national control is now part of the corpus of international law relating to the environment'. ${ }^{72}$ The decision continues by instructing states to account for environmental considerations when determining what constituted necessary and proportionate measures in light of military objectives. ${ }^{73}$ Following the decision, states appear, at a minimum, to be required to abide by the Trail Smelter principle; the outer boundaries of mandatory environmental protection, however, are less certain.

The same concept of neighbourly protection from harm is seen in the 2010 decision by the ICJ in the Pulp Mills case. ${ }^{74}$ The Court decided that the construction and operation of Pulp Mills in Uruguay required the country to undertake a transboundary environmental impact assessment. The Court recognized that a state must take specific measures to prevent harm to its neighbours, thus extending the general principle of the Trail Smelter decision.

\section{Commentary}

MEAs, rules of customary environmental law, and soft-law instruments of IEL afford numerous examples of rules and decisions that establish norms (including

Sonja Ann Jozef Boelaert-Suominen, International Environmental Law and Naval War: The Effect of Marine Safety and Pollution Conventions During International Armed Conflict, Newport Paper No. 15, Naval War College, Newport, December 2000; Margaret T. Okorodudu-Fubara, 'Oil in the Persian Gulf War: legal appraisal of an environmental warfare', in St. Mary's Law Journal, Vol. 23, 1991, pp. $204-206$.

70 ICJ, Corfu Channel Case (United Kingdom v. Albania), Merits, Judgment of 9 April 1949, ICJ Reports 1949 , p. 4.

71 Ibid., p. 22.

72 ICJ, Legality of the Threat or Use of Nuclear Weapons, above note 21, para. 29.

73 Ibid., para. 30 .

74 ICJ, Case Concerning Pulp Mills on the River Uruguay (Argentina v. Uruguay), Merits, Judgment of 20 April 2010. 
on responsibility and liability) relating to environmental damage, and most commentary holds that many of these provisions continue to apply during armed conflict. The next section examines a few key lines of doctrine on the issue.

\section{Commentary on the continued applicability of MEAs in times of conflict}

A number of lines of argument have been developed concerning the question as to whether and to what extent MEAs apply during armed conflict. These include classification theory, intention theory, the context and nature of the MEA, and a sliding-scale system.

'Classification theory' assigns environmental laws to categories that determine their application during armed conflict. For example, Vöneky found that the current categorization methodology assumes IEL applies during times of both peace and armed conflict for three categories of treaties: if the legal instrument expressly says it continues to apply, if it is compatible with armed conflict, or if it is a jus cogens or erga omnes obligation. ${ }^{75}$

By combining classification theory and intention theory - that is, the approach of holding as closely as possible to the original intent of the parties at the time that the treaty was formed - Boelaert-Suominen addressed instances in which an international agreement does not clearly fit into pre-defined categories. ${ }^{76}$ The classification system has been criticized as overly simplistic for complex international relations; conversely, intention theory holds as closely as possible to the parties' original intent at the time that they formed the treaty. ${ }^{77}$ Boelaert-Suominen concluded that, when an MEA does not clearly fit into a particular category, a casespecific analysis of the parties' intention should decide the matter. ${ }^{78}$

A third set of theories holds that MEA applicability during armed conflict can be based on the context and nature of the agreement. Schmitt identifies a theory of differentiation, which holds that continuance of a treaty during armed conflict depends on the consistency of continuance with the context of the agreement. He reasons that, in the absence of express termination language or clear inconsistency, MEAs continue during armed conflict. ${ }^{79}$ Sharp published a related theory according to which a treaty containing no termination clause may be denounced or withdrawn depending on 'the nature of the treaty' ${ }^{80}$ He suggested that,

75 Silja Vöneky, 'A new shield for the environment: peacetime treaties as legal restraints of wartime damage', in Review of European Community \& International Environmental Law, Vol. 9, No. 1, 2000, pp. 20-22; S. Vöneky, above note 50.

76 S. A. J. Boelaert-Suominen, above note 69 , pp. 124-226.

77 For a discussion of intention theory, see Luan Low and David Hodgkinson, 'Compensation for wartime environmental damage: challenges to international law after the Gulf War', in Virginia Journal of International Law, Vol. 35, No. 2, 1995, p. 405. The authors review variations such as analysing the nature of the treaty, the treaty's compatibility with war, or the number of parties to the treaty as different ways to assess intention.

78 S. A. J. Boelaert-Suominen, above note 69, p. 133.

79 M. N. Schmitt, above note 50, pp. 37-38.

80 Walter G. Sharp, Sr., 'The Effective Deterrence of Environmental Damage during Armed Conflict: A Case Analysis of the Persian Gulf War', in Military Law Review, Vol. 137, Summer 1992, p. 23. 
if the treaty is directed at 'sovereign' relations, it should be suspended or terminated during armed conflict. Conversely, a treaty regulating non-military conduct or indirect state interactions should not automatically conflict with a state of hostilities. ${ }^{81}$

Another approach is the sliding-scale theory, which reflects a balancing of environmental protection against military mission success. ${ }^{82}$ It expresses an inverse relationship between IEL's effect and the degree of military operations: when military operations are low-intensity (e.g., during training), environmental laws are in almost full effect, but as the military operations grow the effect of environmental laws lessens. Unfortunately, this approach does not provide concrete explanations or criteria regarding which rules bind a military entity during different types and phases of military engagement.

These lines of argument are not mutually exclusive. A large part of these theories is reflected in the ILC draft articles on the effect of armed conflict on treaties. ${ }^{83}$

\section{Commentary on the continued applicability of customary IEL in times of conflict}

Although customary international environmental law and MEAs are both binding, there may be differences in their application during armed conflict. This distinction may stem in part from the difficulty of determining whether a specific measure is a customary international law and what its precise legal scope is. Most commentators posit that customary IEL applies during armed conflict in a similar manner to MEAs. Citing the ICJ Statute, Parsons emphasized that environmental norms are equally relevant and applicable during armed conflict. ${ }^{84}$

Some support for this argument may be derived from the so-called Martens Clause, which addresses the role of norms, custom, and practice as the law of war develops. ${ }^{85}$ The clause appears in a number of treaty provisions, in particular in the Hague Convention on the laws and customs of war (versions of 1899 and 1907) and in Additional Protocol I of 1977, which are similar in their essential content. They refer to sources of law other than the treaties in which the clause is included. In the 1977 version, the clause reads:

In cases not covered by the present Protocol and other international agreements, civilians and combatants remain under the protection and

81 Ibid., pp. 23-25.

82 John P. Quinn, Richard T. Evans, and Michael J. Boock, 'United States Navy development of operational environmental doctrine', in J. E. Austin and C. E. Bruch, above note 4, pp. 161-165.

83 See ILC, above note 36 .

84 Rymn James Parsons, 'The fight to save the planet: U.S. armed forces, 'greenkeeping', and enforcement of the law pertaining to environmental protection during armed conflict', in Georgetown International Environmental Law Review, Vol. 10, No. 2, 1998, p. 482.

85 Rupert Ticehurst, 'The Martens Clause and the laws of armed conflict', in International Review of the Red Cross, No. 317, 1997, p. 125. 
authority of the principles of international law derived from established custom, from the principles of humanity and from the dictates of public conscience. $^{86}$

In the current stage of development of the international community, it is appropriate to subsume the protection of the environment under all three of the sources of protection enumerated in the clause.

Some observers note that particular international environmental principles presently, or may soon, constitute customary IEL. Soft-law instruments are quoted in this respect. One article notes that 'since [the World Charter for Nature] was adopted by a significant number of States, at the very least the Charter is incorporated in customary international law ${ }^{37}$ The question of whether and to what extent resolutions of international organizations can be used as proof of customary international law can in principle be answered affirmatively, but each case has to be analysed on its own merits. The fact that a resolution was adopted by consent and without declarations to the contrary is an important circumstance. In Military and Paramilitary Activities in and against Nicaragua (Nicaragua v. United States of America), the ICJ based part of its decision on the parties' consent to a UN resolution. The Court explained that, in the instant case, opinio juris - one of the two elements of customary international law - 'may ... be deduced from, inter alia, the attitude of the Parties and the attitude of States towards certain General Assembly resolutions' ${ }^{88}$ This holding of the Court related to the question of whether and to what extent the so-called Friendly Relations Declaration ${ }^{89}$ and the definition of aggression ${ }^{90}$ adopted by the General Assembly constituted customary international law. If widely accepted UN resolutions may constitute evidence of opinio juris, at least some of the soft-law documents previously discussed would be closer to constituting customary international law and becoming binding on all states.

86 Additional Protocol I, Art. 1(2); see also the Preambles of Protocol Additional to the Geneva Conventions of 12 August 1949, and relating to the Protection of Victims of Non-International Armed Conflict (Additional Protocol II), 8 June 1977, and of the Convention on Prohibitions or Restrictions on the Use of Certain Conventional Weapons Which May Be Deemed to Be Excessively Injurious or to Have Indiscriminate Effects, 10 October 1980, as well as the provisions of the four Geneva Conventions of 12 August 1949 on denunciation, Arts. 64/62/142/158.

87 Marc A. Ross, 'Environmental warfare and the Persian Gulf War: possible remedies to combat inten tional destruction of the environment', in Dickinson Journal of Environmental Law and Policy, Vol. 10, 1992 , p. 534.

88 ICJ, Military and Paramilitary Activities in and against Nicaragua (Nicaragua v. United States), Merits, Judgment of 27 June 1986, ICJ Reports 1986, para. 188. In this case, the ICJ found that the US had violated international law by supporting guerrillas in a war against the Nicaraguan government and by mining Nicaragua's harbours.

89 Declaration on Principles of International Law concerning Friendly Relations and Co-operation among States in accordance with the Charter of the United Nations, Annex to General Assembly resolution 2625 (XXV), 24 October 1970.

90 Annex to General Assembly resolution 3314 (XXIX), 14 December 1974. 


\section{Remaining questions}

The preceding argument has shown that there are a number of approaches for determining when and how IEL applies during armed conflict. Nevertheless, the question is open and there is probably no general and simple answer to it. There is no ICJ decision clarifying the issue, and the ILC draft articles leave questions because they offer a variety of considerations to determine the continued application of treaties during armed conflict. In the meantime, MEAs continue to be negotiated, implemented, and enforced, but many of them similarly fail to provide clarification regarding their application during armed conflict. A remarkable exception is shown by the recent articles elaborated by the ILC on the protection of transboundary aquifers, which contain a specific provision on protection in times of armed conflict. ${ }^{91}$ Military manuals of many countries incorporate environmental provisions, yet these tend to focus on the requirements found in IHL. Specific interpretations and practice remain inconsistent. Further analysis and clarification is necessary to make the approaches that have been discussed operational, for example deciding how to implement a sliding scale.

Several general questions of both IHL and IEL have a bearing on the issue discussed in the present article. The first one is the distinction between international and non-international armed conflict. It seems at least plausible that environmental treaties signed by a state on the territory of which a noninternational conflict takes place would not be affected by the existence of this conflict. But what if the treaty applies to parts of the territory that are no longer under the control of the governmental party to the conflict? How far can noncompliance with the treaty be justified on the basis of a state of necessity? ${ }^{92}$ Second, the relationship between the rules concerning the continued application of treaties during armed conflict and the law of neutrality remains to be clarified. If the relations between a belligerent and a neutral state in principle continue to be subject to the law of peace alone, do the duties of abstention and impartiality, being essential elements of the law of neutrality, not modify certain obligations flowing from environmental treaties, be they multilateral or bilateral? Third, what is the relationship between MEAs and customary environmental law during armed conflicts? Fourth, what is the relationship between the private law liability for environmental damages and state responsibility for the causation of the same damages? Modern environmental treaties rely to a great extent on private law liability of the private actors involved. Can this solution be maintained in a situation of armed conflict? Finally, there is the general question regarding the relationship between different MEAs that overlap in certain instances. Whatever answer is given to the question in general, is it the same for the situation of peace and for that of an armed conflict?

91 Article 18 Draft articles on the law of transboundary aquifers, ILC, Report of the International Law Commission, 60th session, 5 May-6 June and 7 July-8 August 2008, GOAR A/63/10, Ch. V, p. 19.

92 See ILC, above note 40, Art. 25. 
This article has attempted to address the question of whether IEL continues to apply during armed conflict. The subsequent questions, which remain unanswered, are when and how it might apply in specific circumstances. For example, if area-based agreements such as the World Heritage Convention and the Ramsar Convention continue to apply, they might protect specified areas in the absence of military necessity. Although the protection offered might be limited, it is a relatively clear application. Conversely, consider the Convention on International Trade of Endangered Species of Wild Flora and Fauna (CITES) in the context of conflict resources. ${ }^{93}$ If the agreement continued to apply, would it spur states receiving such goods to take action against the country of origin, if it were party to CITES? To what effect? How might the analysis change if rebels are engaging in the trade in CITES-listed species? Alternatively, the effect of MEAs may be to create a basis for providing assistance in certain circumstances; or to provide a framework of standards and methodologies, for example for conducting environmental assessment or remediation in conflict contexts (as the UN Compensation Commission borrowed peacetime environmental methodologies for assessing and valuing natural resource damages). These are but some of the questions and scenarios that arise when considering the practical effect and import of IEL during armed conflict.

None of these questions have clearly defined answers, and all involve significant considerations that must be carefully balanced.

\section{Conclusions}

Significant efforts to protect the environment during armed conflict began in the 1970s, mainly in response to events that had taken place during the Vietnam War; there was a resurgence of international attention to the issues following the deliberate oil fires and spills during the 1990-1991 Gulf War. However, the framework that has developed over the past four decades contains numerous gaps and ambiguities.

Although IHL reacted very soon after the development of a broad environmental awareness in the late 1960s, three key gaps or deficiencies remain:

- the regrettably narrow, but also unclear definition of impermissible environmental damage in the provisions explicitly addressing environmental protection during armed conflict;

- unsatisfactory protection of the elements of the environment as civilian objects owing to the easy transformation of such elements into military objectives; and

- doubts as to the practical application of the principle of proportionality to environmental damage, which is so-called collateral damage resulting from attacks against military objectives. 
This article has shown a few ways in which these deficiencies can be remedied. It has also explored the chances that could be provided by a continued application of international environmental law, created essentially for the situation of peace, during armed conflict. In this respect, too, major uncertainties remain.

More clarity regarding the extent of environmental protection during armed conflict is necessary. Some questions (such as how various provisions of IEL apply during armed conflict) require additional research. Others (such as the threshold for 'widespread, long-term and severe' under Articles 35 and 55 of Additional Protocol I) require international action. Belligerents are also called upon to address some of the existing deficiencies on a case-by-case basis through mutual agreement, and the UN Security Council can play a role in this regard. Despite the doubts and challenges discussed above, it appears that international law continues to maintain the concern for future generations - which is the essence of environmental law - in times of war. 